Myroslav Voloshchuk (Мирослав Волощук)

Przykarpacki Narodowy Uniwersytet im. Wasyla Stefanyka w Iwano-Frankiwsku

Centrum Studiorum Mediaevalium, Iwano-Frankiwsk

iD ORCID: 0000-0002-1737-7205
OBLICZA WOJNY

TOM 4 - MIASTO I WOJNA

ŁÓDŹ 2021 • ISBN 978-83-8220-617-3 • s. 27-52

https://doi.org/10.18778/8220-617-3.03

\title{
ГОРОДА РУСИ В ВОЕННЫХ ОПЕРАЦИЯХ ПЯСТОВ ПРОТИВ РЮРИКОВИЧЕЙ (XI - СЕРЕДИНА XIV ВВ.) ЧАСТЬ $1^{1}$
}

\begin{abstract}
Streszczenie. Artykuł poświęcony jest analizie wypraw wojennych Piastów do ziem dynastii Rurykowiczów z uwzględnieniem oblężeń, szturmów i zdobywania ruskich miast lub wkraczania do nich bez oporu. Mając na uwadze ogólnie bardzo aktywny dialog interdynastyczny na wszystkich możliwych płaszczyznach, jednocześnie podkreślamy dużą intensywność najazdów Polaków na sąsiednie ziemie wschodnie. Łączna liczba kampanii w XI-XIV w. zwieńczonych zniszczeniem miast Rurykowiczów lub ich okolic wynosi co najmniej 24. Ponadto w ponad 10 przypadkach wojska Piastów wkroczyły na Ruś, występując jako obrońcy, sojusznicy, strażnicy, wspierający miejscowych książąt, do czego dochodziło zwłaszcza w pierwszych dziesięcioleciach XIII w. Do najbardziej dramatycznych w skutkach należał najazd Bolesława Chrobrego i zajęcie Kijowa w 1018 r., zdobycie Włodzimierza Wołyńskiego przez Leszka Białego w 1207/8 r., a także wyprawa Leszka Czarnego w 1280 r. na Lwów i Przeworsk. Osobno należy rozważyć przykład zdobycia Lwowa przez Kazimierza III w 1340 r. Jednocześnie, z wyjątkiem opisu oblężenia Jarosława w sierpniu 1245 r., nie mamy innych opisów zawierających informacje o zastosowaniu myśli inżynierskiej, detali dotyczących taktyki i strategii przygotowania do szturmu oraz zdobycia przez Piastów ruskich fortyfikacji. Całkiem możliwe, że kronikarze po prostu nie przywiązywali do tego dużej wagi.
\end{abstract}

Słowa kluczowe: Piastowie, Rurykowicze, miasta ruskie, wojna, oblężenie

Общеизвестным фактом ведения боевых действий в Средневековье является пристальное внимание руководства армий к городам и крепостям. Понятно, что укрепценные поселения создавались не только в качестве убежища Аля жителей, места пребывания и проживания правителей, центров мобимизации человеческого потенциала и ресурсов,

\footnotetext{
${ }^{1}$ Вторая часть статьи находится в пятом томе серии „Oblicza Wojny”.
} 
транспортных коммуникаций, но и, понятно, со временем превращахись в места накопления разцичных богатств. Поэтому сражаясь, штурмуя, осаждая, Аця противоборствующих сторон очень важно было заполучить обоз побежАенных (своего рода grand prix побеАителю) - нереАко еще Ао полного окончания битвы, а взяв штурмом укрепленное поселение, „отбцагодарить” воинов разрешением в течении нескольких Аней грабить его и т. А. На протяжении всей истории человечества в этом плане мало что изменимось.

В данном отношении военные конфликты XI-XIV вв. польских Пястов с руськими Рюриковичами вполне вписываются в общий контекст. Обе Аинастии, как уже неоднократно отмечалось в научной $и$ тературе, подАерживали разносторонние чрезвычайно тесные связи, а в случае правителей Руси - значительно активнее мюбых Аругих западных или северных соседей. В частности Авусторонних браков, несмотря на конфессиональные размичия, руськие князья, а в XIII в. - короли, наибольшее количество закцючаци именно с Пястамиㄹ․ Кроме того, учитывая близкое соседство, относительно слабо защищенную с обеих сторон естественными препятствиями протяжную в пространстве границу и ее

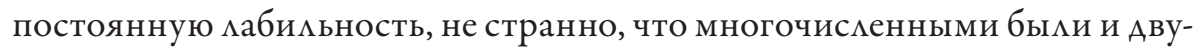
сторонние конфмикты, войны, причины и характер ведения которых за века не раз менямись, а городские стены и врата с обеих сторон, безусмовно неоднократно станови ись объектом ожесточенных нападений.

В первой части Аанной пубцикации попытаемся обобщить и подытожить роль города на Руси во времена военных кампаний Пястов в земли Рюриковичей XI-середины XIV вв., акцентируя внимание на непосредственно связанных с осаАами, штурмами, использованием польскими войсками инженерной мысли повествованиями источников разной провениенции. При этом, учитывая большое количество нападений, в расчет не будем брать не сопровождавшиеся какими-либо военными Аействиями в отношении городов. Также по понятным тематическим

2 Итоги многолетних исследований польских, украинских, российских и колмег из Аругих стран, а также собственные статистические обобщения vide: M. Voloshchuк, Ruthenian-Polish matrimonial relations in the context of the inter-dynastic policy of the house of Rurik in the 11th-14th centuries: selective statistical data, „Codrul Cosminului” 2019, vol. XXV, no. 1, s. $95-126$. 
причинам не рассматриваем военных походов руських князей в земли Пястов. При этом попытаемся учесть и сложно верифицируемые путем изучения источников случаи, а также сопровождавшиеся опустошением городские окраины.

\section{Случаи (или попытки) захвата поляками руських городов}

Остав яя „за скобками” восточную политику Мешка I († 992) и Болеслава I Xраброго $(† 1025)$ в конце X в. (особенно на фоне сложной Аискуссии о хронологии изменения Аинастической принаАлежности Перемышия $\left.{ }^{3}\right)$, победоносный поход последнего на Киев в 1018 г. (см. Аалее), завершившийся также заполучением (в Аанном случае непонятно насимьственным $и$ путем) приграничних по Бугу градов („грады Червьньскыæ заæ собъ” $)^{4}$, возможно первым, но не подтвержденным до конца источниками XI в., случаем захвата подконтрольных (вероятно) кому-то из руських князей путем военных мероприятий городов Аатируется 1071 или 1074 г. (согласно Annales Яна Алугоша, † 1480).

Собственно речь о частично отображенных в так называемой Великопольскойхронике ${ }^{5}$, позже в более детацьной версии Я. Алугошем каких-то военных Аействиях Болеслава II Смелого ими ЩеАрого († 1081/2) поА Перемышлем ${ }^{6}$, свидетельствующих о штурме и взятии не только крепости

3 A. ŻA Ki, Przemyśl w czasach Bolestawa Chrobrego i Mieszka II, „Rocznik Przemyski. Archeologia” 2005, t. 41, z. 2, s. 145-156. Из обобщенного в последние годы vide: K. Kollinger, Polityka wschodnia Bolestawa Chrobrego (992-1025), Wrocław 2014, s. 285-295; P. HudÁčEK, Castrum Salis. Severné pograničie Uhorska okolo roku 1000, Bratislava 2016, s. 58-60; A. Jusupović, «Червень и иныцеграды» оr «Гроды Червеньскьця»? History of the domain of Cherven' in the written record (10th-13th Centuries), [w:] From Cherven' Towns to Curzon Line Od Grodów Czerwieńskich do linii Curzona, ed. M. WoŁoszyn, vol. 3: Uźródet Europy Środkowo-Wschodniej/Frühzeit Ostmitteleuropas, Kraków-Leipzig-Rzeszów-Warszawa 2017, s. 43-45 etc.

${ }^{4}$ Ипатьевская летопись, [w:] Полное собрание русских летописей [Аалее: ПСРА], с предисловием Б.М. КАосСА, т. 2, изА. 2, Москва 2001, s. 131.

5 „ad alios fines Russie se transtulit ibique per plures annos castra Ruthenorum [акцент наш. - M.B.] potenter expugnas", Chronica Poloniae Maioris, recen. et annot. B. KürbIs, [w:] Monumenta Poloniae historica [Aалеe: MPH], Nova series, t. 8, Warszawa 1970, s. 20.

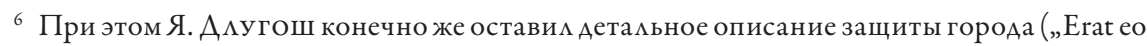
tempore urbs valida et multitudine civium advenarumque et omni bellico apparatu instructa, fossis 
города, но и Аругих близ межащих более ими менее крупных насеменных пунктов ${ }^{7}$. Проблематичность отождествления указанной территории именно с владениями Рюриковичей (Ааже учитывая постоянное аппе$\Lambda$ ирование помьского автора XV в. к руським защитникам Перемыш $я^{8}$, что также может быть не более чем отображением современной Я. Алугошу идентичности местных жителей) связана, не в послеАнюю очереАь, с описанными в источниках конфмиктами князя Болеслава с венгерским королем Соломоном († 1087). Тот, воспользовавшись политической нестабильностью на Руси в конце 60-х гг. XI в., с целью предотвращения польского нападения, теоретически мог кратковременно расширить свои владения вплоть до пределов Перемышля9. В видим из описанных источниками Аействий князя Болеслава в Аанном

quoque profundis et aggeribus in altum porrectis, amne quoque Szan, qui urbem a parte septemtrionali preterfluit, munit"), а также особенностей его осады войсками князя Болеслава (DLUgossir Joannes, Annales seu Cronicae incliti regni Poloniae, lib. 3-4, Warszawa 1970, s. 104).

7 „Boleslaus Polonorum rex civitatem et arcem Premisliensem [акцент наш. - М.В.] саріt”


Аревняя Русь в «Польской истории» Яна Акугоша (книги I-VI): текст, перевод, комментарии, Москва 2004, s. 394, прим. 164); „Boleslaus rex Polonorum totam Russiam suo imperio subiicit devicto Wszewoldo duce [...] effusosque Ruthenos victores secuti magnum illorum numerum ad castra reduxerunt [акцент наш. - M.B.]", Dlugossir JoAnnes, op. cit., lib. 3-4, s. 112-113). Vide: Н. ЩАВЕ $\mathrm{EBA}$, op. cit., s. 397, прим. 174. Vide: „rex Boleslaus fuerit bellicossissimus, qui eciam septem annis cum suis baronibus et satrapis in expedicione permansit bellica apud Russiam", Cronica Petri comitis Poloniae accedunt carminis Mauri fragmenta, edidit, praefatione notisque instruxit M. Plezia, [w:] MPH, seria 2, t. 3, Kraków 1951, s. 5.

${ }^{8}$ Dlugossin Joannes, op. cit., lib. 3-4, s. 104-105 (Przemisliam opidum multorum Ruthenorum; ex urbe Ruthenis; Ruthenis in arcem; multitudo Ruthenorum cum coniugibus et pignoribus urbe deserta; milites Ruthenorum).

9 „Salomon rex Hungarorum cum suo exercitu in montanis Russie et Hungarie [акцент наш. - M.B.] ad suum regnum volens prohibere ingressum occurit", Chronica Poloniae Maioris, s. 21. В словацкой историографии бытует мнение о возможном столкновении войск короля Саломона с князем Болеславом в окрестностях града Салис (castrum Salis). Vide: P. HudéčEK, op. cit., s. 197, 305. Свою не безспорную версию принаАлежности Галича на протяжении некоторого времени в XI в. Пястам в свое время преАложил Генрих Пашкевич (Н. PASZKIEWICZ, Poczatki Rusi, z rekopisu przygotował K. SторкA, Kraków 1996, s. 446-455, а также новейший украиноязычный перевод материала: Г. ПАшкевич, Початки Галича, [w:] Галич. Збірникнаукових пращь, вип. 5, реА. М. Волощук, Івано-Франківськ 2020, s. 96-108). Кажется, она так и не вызвала надлежащего внимания историков (Vide: А. Головко, Аревнял Русь и Польша в политических взаимоотношениях X - первой трети ХІІІ вв., Киев 1988, s. 52-53). 
регионе мотивов в отместку за насесенный Изяславом Ярославичем ему ущерб в Киеве и Киевской земле в 1069 г. (см. Аалее $)^{10}$.

С Аругой стороны существуют также серьезные сомнения насчет реацьности описанных польскими источниками XIII-XV вв. событий, веАь они не наш и должного внимания (а по могике - Аолжны быми найти) на страницах Повести временных мет Нестора, начавшего в Киеве работать с текстами метописи в 70-е гг. XI в. ${ }^{11}$ Учитывая сложность верификации приведенных материалов, не отбрасываем также версии и о том, что Я. Алугош мог (специально ими несознательно) спутать события кампании Болеслава Храброго 1018 г. с походами Болеслава Смелого ими Щедрого 1069 и 1077 гг. в подАержку князя Изяслава Ярославича († 1078), преувеличив и обосновав возвращение когда-то утерянного Пястами на пограничье имущества. Упомянув Аанные известия, оставим их Аця Аацьнейшего детацьного анализа в будущем.

Аинастическая принадлежность городов вдоль Сана, как общеизвестно, надолго утвердилась в середине 80-х гг. XI в. за Рюриковичами с вокняжением в Перемышле и других центрах будущей Галицкой земли сыновей отравценного в 1067 г. в Тмутаракани Ростислава Володимеровича - Рюрика († 1092), Володаря († 1124) и Васимька († 1125).

Вероятно какие-то военные Аействия в окрестностьях Берестья, отображенные в Поучении Володимира Мономаха ${ }^{12}$, князь Болеслав также провец в 1073/4 г. Я. Алугош, скорее всего спутац Аанный поход с очередным восстановлением недавно помазанным 25 декабря 1076 г.

10 „Boleslaus [...] versus Premisliam procedit et quasdam municiones et opida circa Szan fluvium [акцент наш. - М.B.] consistencia partim voluntate, pertim metu aut vi recipit”, Dlugossii Joannes, op. cit., lib. 3-4, s. 103-104, vide: Н. ЩА ВЕ Ав ВА, op. cit., s. 394, прим. 164. Вопрос о вмешательстве польского правителя в борьбу за венгерский престол оставим в Аанном месте „за скобками”, отправив Читателя к соответствующему разделу последнего биографического очерка о Болеславе Смелом или Щелром (N. Delestowicz, Bolestaw II Szczodry. Tragiczne losy wielkiego wojownika 1040/1042 - 2/3 IV lub 1081 albo 1082, Kraków 2016, s. 329-334).

11 A. Jusupović, Żaden książe nie wszedt tak daleko w ziemię lacka jak Wtodzimierz Wielki. Wydarzenia z końca X wieku i ich recepcja w XIII wieku, [w:] Materiaty V Kongresu mediewistów polskich, red. A. Janeczek, M. Parczewski, M. Dzik, t. 3: Pogranicza w polskich badaniach mediewistycznych, Rzeszów 2019, s. 69-70.

12 „тоєже зимъ1. тои посласта Бе|рестию брата на головнъ . иде бАху пожгли . тои ту бцюдъ городъ тихъ", Ааврентьевская летопись, [ш:] ПСРА, т. 1, Москва 2001, s. 247. 
королем Поцьши на киевском престоле в 1077 г. Изяслава Ярославича. Путь к столице, по словам помьского автора XV в., проходим волынскими земцями, гАе король Болеслав осаАим крепость Волынь, взяв ее спустя шесть месяцев ${ }^{13}$, что не может хотя бы с хронологической точки зрения соответствовать Аействительности Ааже потому, что изгнанного князя общими усимиями возобновици на отцовском престоле 15 июля 1077 г. Задержка помьской армии под Волынем, описанные Я. Алугошем переговоры с Аругими князьями Руси, планы короля Болеслава овладеть также волынским Володимиром и Холмом (sic!), - на самом Аеле начавшимся возводиться только в 30-х гг. XIII в., - вряА $и$ и помогла бы Аанному плану реализоваться. В конце концов, абстрагировавшись от его очевидних и заведома осознанных ошибок, не Аает надежного подтвержАения авторського видения описываемых событий польского хрониста внимательный текстологический анациз известий указанной части третьей книги Annales ${ }^{14}$.

После похода князя Владислава Германа († 1102) в союзе с Аавидом Игоревичем († 1112) ваоль реки Буг под город Берестье в 1097/8 г. $(?)^{15}$, завершившегося примирением польского правителя со Святоскавом Изяславичем („ста Стополкъ в градь . а $\Lambda$ Ахове на Бугу . и сосласА

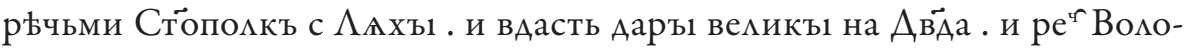

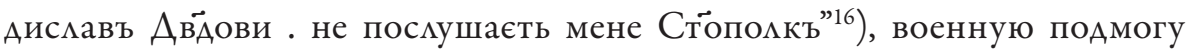
„с $\Lambda$ яхы” в 1121 и 1123 гг. под стены Червена и волынского Володимира, соответствено, АважАы приводи Я Ярослав Святополкович $(† 1123)^{17}$. ПоА непосредственно укреплениями Володимира князь Ярослав собственно и погиб от нападения Авух вероятно поляков-изменников.

Вполне возможно по результатам кампаний Ростиславичей в земли Пястов в ответ на коварное пленение в 1122 г. Петром ВАостовичем князя Володаря († 1124) - Болеслав Кривоустый $(† 1138)$ в 1125 г. совершим

13 "Boleslaus rex Poloniae castrum Wolhin sex mensibus obsessum capit", Dlugossir JoanNES, op. cit., lib. 3-4, s. 110.

${ }^{14}$ Н. ЩАВЕ $\Lambda$ ЕВА, op. cit., s. 397, прим. 172-174.

15 Ипатьевская летопись, s. 243, vide: Ааврентьевская летопись, s. 269-270; Аетопись по Воскресенскому списку, [w:] ПСРА, с предисловием Б. Кцосса, Москва 2001, т. 7, s. 15.

${ }_{16}$ Ааврентьевскаллетопись, s. 269.

17 Ипатьевская летопись, s. 286-287, vide: Аетопись по Воскресенскому списку, s. 25. 
опустошитемьное нападение на Перемишиьскую землю, АойАя вероятно до Гацича ${ }^{18}$.

В масштабном походе 1146 г. киевского князя Всеволода Ольговича $(†$ 1146) „к Галицю на Володимерка [Володаревича, † 1153. - М.В.]”19 приняли участие и войска Болеслава Кудрявого († 1173). Кампания имела все шансы завершиться, в частности, взятием Звенигорода, но после того, как наступавшие „зажгоша городъ въ трехъ мъстехъ. гражане же Биею помощью оугасиша. Бъ же и ста̃æ Бца̃ избави городъ . $\overline{\text { }}$ мютыæ рати”20.

Непонятно, с какими результатами в 1163 р. „воеваща $\Lambda$ Ахове школо Чьрвьна" 21 . В присущей Винцентию КаАлубку манере, но без особых поАробностей, описаны осада симами Казимира Справедиивого († 1194) в 1182 г. Берестья ${ }^{22}$, как и Аамьнейшее столкновение „сum principium Laodimiriensium, cum Galiciensium”23. Следствием коварного захвата в 1188 г. венгерским королем Белой III († 1196) и его сыном герцогом

${ }^{18}$ Dlugossit Joannes, op. cit., lib. 3-4, s. 303; vide: Н. ЩАвецева, op. cit., s. 418, прим. 270. Кроме свидетельств Я. АлугошА намеки на Аанный поход содержит также позднего происхождения Хроника комеса Петра: „Ipse itaque Petrus [...] civitatem Gallaciam [акцент наш. - M.B.] cum magna strage populorum delevit" (Cronica Petri comitis, s. 7). Общий межАинастический фон в первой трети XII в. отношений Пястов с Ростиславичами позволяет осторожно взять приведенные Аанные к сведению. Хотя появцение названия Галича в источниках более позднего происхождения может иметь и вполне субъективное объяснение. Vide: B. Wıodarski, Ruś w planach politycznych Bolestawa Krzywoustego (1102-1138), „Zeszyty Naukowe Uniwersytetu Mikołaja Kopernika w Toruniu. Nauki humanistyczno-społeczne”, 1966, Historia II, z. 20, s. 52-54. Vide: K. BENYsKiewiCz, Zniszczenie Wiślicy w 1135 roku w świetle przekazów źródtowych i literatury historycznej, część I: Źródta, „In Gremium” 2020, t. 14, s. 40.

19 Ипатьевская летопись, стб. 319.

${ }^{20}$ Ibidem, стб. 320.

${ }^{21}$ Ibidem, стб. 522.

22 "Qui Rusiam ingressus, primam Brestensium urbem aggre|ditur [акцент наш. - М.B.], tam uiris quam arte ac loci situ munitissimam ibsidionum < que $>$ undique artat angustiis", Magistri Vincentii dicti Kadłubek, Chronica Polonorum, ed. M. Plezia, [w:] MPH, seria II, t. 11, Kraków 1994, s. 156.

${ }^{23}$ Magistri Vincentii dicti Kadłubek, op. cit., s. 157, vide: Dlugossi Joannes, Annales seu Cronicae incliti regni Poloniae, lib. 5-6, Warszawa 1973, s. 129. События 1182 и 1189-1190 гг. перемешались в narratio автора так называемой Великопольской хроники (Chronica Poloniae Maioris, s. 61-62), а позже в бомее широкой версии и в Annales Я. А уугошА. В частности автор $\mathrm{XV}$ в. указал, что осада и штурм Алимись 12 Аней (,infra dies duodecim vincit et conquirit”), а после взятия Берестья князь Казимир укрепи его новыми оборонительными сооружениями и гарнизоном (Dlugossir JoAnNes, op. cit. lib. 5-6, s. 128). Учитывая неоднократно доказанное текстологическим анализом (Н. ЩАВЕ $\mathrm{EBA}$, op. cit., s. 434-436, прим. 317-319) умение 
Андреем (будущий король Андрей II, † 1235) престола в Гахиче, обманутый местный князь Володимир Ярославич († 1198/9) сначала пытался вернуть утраченное с помощью подАержки императора Фридриха Барбароссы († 1190) и выше упомянутого краковско-сандомирского князя Казимира. ОАнако, не получив ожидаемой помощи, смог укрепиться в Перемышле, откуда на протяжении мая - августа 1189 г. разоря земли польского правителя. В отместку тот, как считает российский историк Михаим Юрасов, 15 августа 1189 г. совершим поход и захватиц город, а позже все же помог изгнаннику вернуть Галич (см. Аалее) ${ }^{24}$. Вероятно, на фоне Аанного успеха князь Казимир в 1193 г. смог также на какое-то время присоединить к своим владениям расположенный на Буге важный с транзитной точки зрения Аорогичин ${ }^{25}$.

Аахьнейшей особой военной активностью при взятии штурмами, контроле городов на Волыни и в Галичской земле в первой четверти XIII в. отметился причастный к гибели 19 июня 1205 г. под Завихостом самодержца всея Руси Романа Мстиславича сын Казимира Справедиивого краковско-сандомирский князь Аешек Белый († 1227). Например его отряды, на фоне событий произошеАших годом ранее, Авинулись весной 1206 г. в подАержку организованных против малолетних Ааниима $(† 1264)$ и Васимька († 1269) Романовичей Ольговичами и князем Рюриком Ростиславичем († Ао 1212 или 1215/6) объединенных сим к волынскому Володимиру, но поА его стенами венгерский „коромь [Андрей II. - М.B.] же шмиривъ $\Lambda$ Ахъ” ${ }^{26}$. ОАнако уже через год город перешел поА контроль Святослава Игоревича († 1210/11), контролировавшего вместе с братьями Володимиром († после 1210/11) и Романом († 1210/11)

Я. АһугошА Аобавлять к отображаемым событиям „отсебятину”, Аопуская очевидные ошибки, воздержимся от Аальнейшей оценки приводимого пассажа.

${ }^{24}$ В немного искаженном виде vide: Chronica Poloniae Maioris, s. 63-64; vide: DlugossiI Joannes, op. cit., lib. 5-6, s. 141-142. Vide: М. Юрасов, Роль Перемьиия в борьбе Владимира Ярославича за возвращение Галича (1189-1190), [w:] Colloquia Russica, red. V. NAgirny, T. PUDŁOCKI, series II, t. 1, Kraków 2013, s. 75-76.

${ }^{25}$ Dlugossir Joannes, op. cit., lib. 5-6, s. 152-153. Vide: О. Головко, Західнобузькі міста Холм і Аорогочин у політичній діяльностікороя Аанила Романовича, [w:] Арогичин 1253, реА. О. ЖерНок єєє, М. ВолОЩУК, І. ГУРАК, Івано-Франківськ 2008, s. 54; A. Jusupović, Przynależność polityczna Drobiczyna w XII i pierwszej potowie XIII w., [w:] Арогичинъ 1253, реА. О. ЖЕРнок АЕєв, М. ВолОщук, І. ГУрАк, Івано-Франківськ 2008, s. 162.

\footnotetext{
${ }_{26}$ Ааврентвевская летопись, стб. 427. Vide: Аетопись по Воскресенскому списку, s. 113.
} 
кратковременно при венгерском протекторате (sic!) Гацичскую и значительную часть Волынской земель. Изменения на княжестком престоле в волынском Володимире спровоцироваци в 1207/8 г. похоА Аешека со своим младшим братом Конрадом († 1247) с целью вокняжения в городе племянника покойного князя Романа - Александра Всеволодовича († после весны 1234). Хотя „Шт[ъ]вориша им[ъ] ворота волшАи|мер[ь]ци, рекоуще: «се ес[ть] с[ы]ншвець Романови»”, какая-то часть несогласных горожан укрылась за стенами Успенской церкви, спровоцировав штурм храма поляками („Твердым[ъ] же бывшим[ъ] Аверем[ъ], не могоша исъсьч[и]”), вероятно по результатам котрого и, в целом, занятия княже-

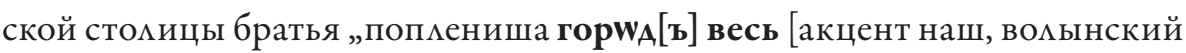
Володимир. - М.В.]"27.

Отряды краковско-сандомирского князя принимахи участие и в масштабном походе венгерских войск поА преАводительством паматина Пота метом 1210/11 г. против князей Игоревичей (занимавших в то время престолы в Галиче, Перемышие и Звенигороде). По ходу кампании сопротивление оказами жители Звенигорода („Звинигорша[ь]

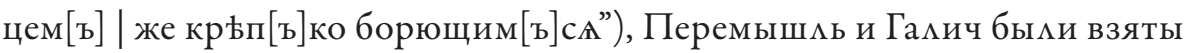
без боя ${ }^{28}$. Зафиксированная Катацогами помьських епископов, а также Annales Я. Алугоша причастность Аешека Белого к повторному плене-

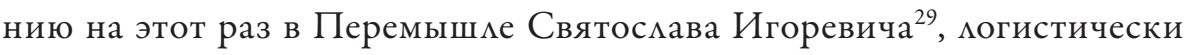
позволяет осторожно Аопускать участие польских войск и в Аальнейшей осаде и взятии Звенигорода, несмотря на отсутствие expressis verbis упоминаний об этом в хронике Романовичей, за искмючением того,

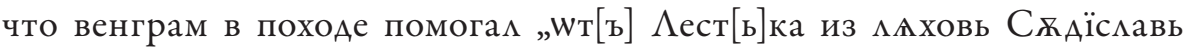
Берна|тович[в]"30.

27 Chronica Galiciano-Voliniana (Chronica Romanoviciana), ed. D. DĄBRowski, A. Jusupović, [w:] MPH, Nova series, t. 16, s. 18, Kraków-Warszawa 2017 (тут и Аалее - комментарии составителей, учитывающие результаты новейших исследований ктеме). Без конкретизации боевых действий в городе сюжет известен и Я. Алугошу (Dlugossi JoAnnes, op. cit., lib. 5-6, s. 199-200, 212-213, 232).

28 Chronica Galiciano-Voliniana, s. 34.

29 Catalogi episcoporum Cracoviensium, recensuit et annotavit J. Szymański, Nova series, [w:] MPH, Warszawa 1974, t. 10, f. 2, s. 90; vide: Dlugossir Joannes, op. cit., lib. 5-6, s. 200.

${ }^{30}$ Chronica Galiciano-Voliniana, s. 34. 
Позже в 1213 г. Аешек Белый, принимая участие в мирном распредемении сфер влияния на Волыни, сначала „прїиде [...] | к Бемзоу”з1, а на рубеже 1213/14 г., своевременно „по^ Аанима [Романовича - М.В.] с Камен[ь]ца, а О|лез̆андра [Всеволодовича. - М.В.] из Волшдимера, а Всевомода [Мстиславича. - М.В.] из Белза, кого|жАо их[ъ] съ своими вои"32, Авинулся против венгерского ставленника в Галиче боярина Володислава Кормильчича: „Потом[в] же $\Lambda$ естко не може прїати Галича, но шеА[ъ] | воева около ТеребовмА и около Мокмекова, и | ЗбарАжа, и Быковен[ъ] [акцент наш. - М.В.] взАт[ъ] быс[ть $]$ Аххы и роус[ь]ю, и взА $\mid$ пльн[ъ] ве-

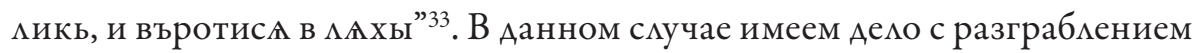
окрестностей упомянутых городов, нанесением материального ущерба, но без упоминания взятия хотя бы одного из них. В Аюбом случае военные затраты 1213/4 г. Аешек Бемый компенсироваА под конец 1214 г. не только престижным с Аинастической точки зрения (речь в Аанной части шла о матримониальном союзе), но и политически выгодным с Андреем II договором о разделении сфер влияния в Галичской земле и на Волыни.


Аалее), контролируя их около года с небольшим. ОАнако венгерско-польское обострение отношений на протяжении 1215 г. и вкцючение в борьбу за Галич по инициативе Аешека Белого князя Мстислава Мстиславича († 1228) завершились не только потерей поляками в пользу Арпадов не Аалее начала 1216 г. Аанных приграничных насеменных пунктов ${ }^{34}$, но и в 1217/8 г. - впользукрепнущих сыновей Романа Мстиславича - нескольких городов Волыни („Берестїй, и Оугровескь, и Верещинъ, | и Столпъе,


ваша по Боугоу" ${ }^{36}$, но, очевиАно, - без какого-либо результата.

Примирившись с недавно вернувшимся из крестового похода венгерским королем, позАней осенью 1219 г. вместе с войском Арпадов

31 Ibidem, s. 45.

32 Ibidem, s. 49.

33 Ibidem, s. 51.

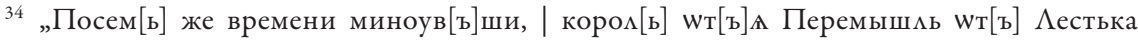
и $\Lambda$ юбачев”, Ibidem, s. 55.

35 Ibidem, s. 59-60.

36 Ibidem, s. 60. 
подразделения Аешека Белого сначала появимись под Перемышлем ${ }^{37}$, в окрестностьях Городка ${ }^{38}$, потом - Галича „на Кроваком[ь] [sic] Бродоу”з и в целом, по результатам успешной кампании - в самой столице Галицкой


Ао конца марта 1221 г., когда по результатам очередной военной операции руських князей бы захвачен войсками Мстислава Мстиславича. СопровожАавшие Коломана († 1241) и его жену Саломею († 1268) венгерские и польские войска понесли тяжелое поражение, частично вместе с венценосной четой попав в плен ${ }^{41}$. Вероятно где-то в канун взятия Гацича „прїйде $\Lambda$ ест[ь] ко на Аанима к[ъ] Щекаревоу, | боронА ити емоу на помощь Мьстиславоу, тестеви | своемоу"42. Тем не менее попытка связать Ааниима боевыми действиями на Волыни завершимась неудачно.

Освобождение королевских пленников до начала 1222 г., поражение объединенных руських сим от монголов на речке Кацка в конце мая - начале июня 1223 г. и Аамьнейшие межкняжеские распри 1225 г. привели к тому, что Ааниим Романович поАкцючим Аешека Белого к войне со своим тестем, подстрекаемым против него Александром Всеволодовичем. ОАнако „Аанимови ж[е] прїехав[ъ]шю в мАхы и възвеА[ъ]шю|кнАsА

37 „Аронови же тогда тысАщю Аръ|жащю в Перемышли, избъже преА[ъ] ними” (Ibidem, s. 62), что свидетельствует о взятии города без сопротивления.

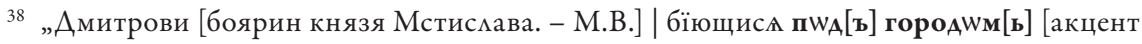
наш. - М.В.], прійдоша на н[ь] оугре и мАхове, || и побъжен[ъ] Амитрь”, Ibidem, s. 63.

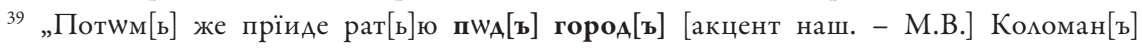

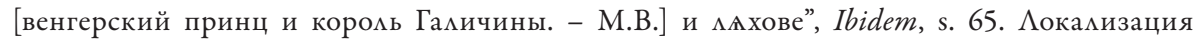
топонима „Кровавый брод” позволяет разместить его в непосреАственной близости от укреплений Гамича.

40 Ibidem, s. 75-76. vide: M. Homza, Uhorsko-pol'ská kronika. Nedocenený prameň k dejinám strednej Európy, Bratislava 2009, s. 180.

${ }^{41}$ Chronica Galiciano-Voliniana, s. 81-82; vide: детали приступа галичской крепости войсками князя Мстислава: Dlugossir Joannes, op. cit., lib. 5-6, s. 204-209. О венгерском аспекте событий vide: М. Волощук, Руські бранці Арпадів та угорські бранці Рюриковичів XI-XIII cm.: nорівняльний аспект, „Bуzantinoslovaca” 2020, t. 7, s. 125-127. В целом присутствие каких-то „Аяхов” в Галиче во княжение Мстислава Мстиславича фиксируют несколько граффити храма Св. ПАнтелеймона (В. Корнієнко, Eпіграфіка сакральних пам'яток Гаıича (XII-XIX cm.), [w:] Галич. Збірник наукових прачь, серія 2, вип. 3, реА. М. ВолощукА, Івано-Франківськ 2018, s. 184-186, 280-281; О. Гпппгус, С. Мгхеєв, Нові методики досліджень та прочитання графіті иеркви Святого Пантелеймона ХІІ-ХІІІ cm. [w:] Галич. 3бірник наукових пращь, вип. 5, реА. М. ВолощукА, Івано-Франківськ 2020, s. 26-27).

${ }^{42}$ Chronica Galiciano-Voliniana, s. 77. 
$\Lambda е с т[\mathbf{b}]$ ка, поиде противоу емоу [...] стрьтив[ъ]ши ж[е] | имь рат[ь], възгнаша въ граА[ъ] Бемзъ и замамо и горшА[а] | не взАша [акцент наш. - М.В.]"«3 , о подробностях чего, при отсутствии сведений источников, мы можем только догадываться. Обезвредив одного соперника, в том же году „Аа|нимоу ж[е] кнАлю въевав[ъ]шю с $\Lambda$ Ахы землю галиц[ъ]коую [князя Мстислава. - М.В.] | и окомо Мюбачева [акцент наш. - М.В.],

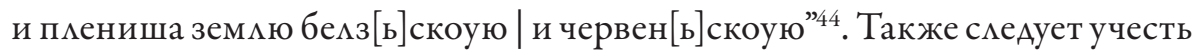
вспомогательную роль польских сиц в кампании короля Андрея II против князя Мстислава на рубеже 1226/7 г.: „бь же с королем[ь] Пакославь | с $\Lambda$ Ахы $"$. Хотя описание кампании свидетельствует о захвате войсками во главе с венгерским правителем Перемышля („Юрьеви то|гАа тысАщю Аръжащю преда Перемышиь”), Теребовли („поиде кором[ь] к Теребовлю и взА | Теребовць”) и Тихомля („пойде к Тихомлю и възА Тихомль”), жестоком сражении в окрестностях Кременца („бисА пшА[ъ] КремАн[ь] цемь”), о постое в Звенигороде (удерживаемом моямьным к королю боярином Судиславом - „Королеви ж[е] став[ъ]шю въ Звинь|городы”), а также попытке взятия Галича („посла вои свои къ Галичю”) 46 сложно понять, какие функции во время похода отводимись краковским отрядам и везде $и$ находимись они под началом Андрея II.

Неожиданная гибель под Гонсавой 24 ноября 1227 г. Аешека Белого, повлекца Аовольно Алительную паузу в притязаниях Пястов на соседные восточные земли. ОАнако в составе войск руських князей их подраздемения продолжали принимать участие в военных походах на сосеАние земки. Например нам известно о каких-то „цяхах” (скорее всего из Мазовии), помогавших отбить Аанииму Романовичу нападение млаАшего короця Белы IV метом 1230 г. ${ }^{47}$ Анацогично зимой 1235 г. помощью „цяхов” (на этот раз скорее всего из Краковско-Сандомирской земли) при попытке отобрать, - видимо, безуспешной, - Гацич у князя Михаима

43 Ibidem, s. 103-104.

44 Ibidem, s. 104.

45 Ibidem, s. 113-114.

46 Описание кампании vide: Ibidem, s. 112-117. В связи со сложностями разграничения функций польской и венгерской армий, пребывание АнАрея II в Звенигороде рассматриваться во второй части Аанной публикации не будет.

47 Ibidem, s. 151. 
Всеволодовича († 1246) пользовался Васицько Романович ${ }^{48}$. В ответ летом 1236 г. „възве [ъ] бо блше на Аанима Ми|хайло и ИзАславь [Володимирович, † после 1255. - М.В.] ^Ахы, и роусь, и половець мншж[ь]|ство. КонАратови ж[е] став[ъ]шю, гАе н[ы]нн граА[ъ] Хоммь [акцент наш. - М.В.] стоит[ь], | пославшю емоу къ Червноу [акцент наш. - М.В.] воевати" Попытки взятия Червена, закончимись Аһя мазовецкого князя ничем ${ }^{50}$, а к осени враждующие стороны оумиристасА.

Монгоцьское нашествие 1240-1242 гг. изменимо порядок межАинастических взаимоотношений, посодействовав дацьнейшему на какое-то время сбцижению Романовичей с мазовецкими князьями против краковско-сандомирских. Так в середине июля 1243 г. „Аанимови же со | братомъ Васимкомъ заративъшимасл со Болеславом[ь] [Стыдиивым, † 1279.


рми дорогами [...] В[ъ] земши полонъ, возвра|тишасА” воеваша | же шкомо Андреева [акцент наш. - М.В.]”, но после контратаки Романовичей поА Аюблином „начаша просити мимости” ${ }^{2}$.

В августе 1245 г., при согласии вдовы Аешека Белого Гримиславы и под началом сандомирского воеводы ФАориана Авданца, поляки приняли участие в кампании венгерского бана Фими и князя Ростислава Михаймовича († Ао 1264) под город Ярослав ${ }^{53}$. В то же время „Нарочитые болри и инїи бо $\mid$ Алхове избъгли бАхљ изь земль, хотАще ити къ $\mid$ Аанимови” хотя вероятно старший Романович мог рассчитывать искцючительно на помощь мазовецких союзников: „Посласта къ Кондратови, | рекоуща,

48 Ibidem, s. 194.

49 Ibidem, s. 197.

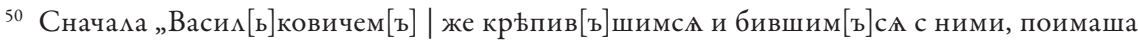

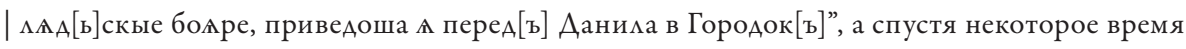

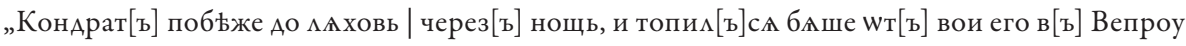
| мншж[ь]ство”, Ibidem, s. 197-198.

51 Ibidem, s. 259-260. Vide: также: J. GAw RON, Najazdy książat halicko-wtodzimierskich na ziemię lubelska w latach 1243-1244 w świetle średniowiecznych źródet narracyjnych, „Koło $\mathrm{Hi}$ storii" 2015, t. 17, s. 53-61.

52 Chronica Galiciano-Voliniana, s. 260-261.

53 Ростислав Михайлович „иде в $А$ А $[$ ь]скоую | землю, и молисА Иестьковой [вдове

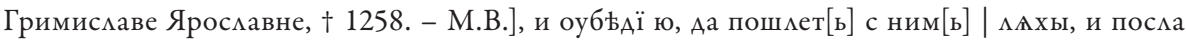
с ним[ь] воА”, Ibidem, s. 271.

54 Ibidem. 
æко «тебе АьлА изыдоша на наю мАхове, æко | помощника ти есвђ». Пославшю ж[е] емоу помощь"55, которая все равно не успема прибыть вовремя. Венгерско-польская армия „прїиде на граА[ъ] Ерославль [...] видьв[ъ] же крьпшк[ъ] граА[ъ], пойде к Перемышкю"56. Найдя здесь необ-


тозем ьць мншгые, съсқаы ратные и град|ные и порокы”), князь Ростис-

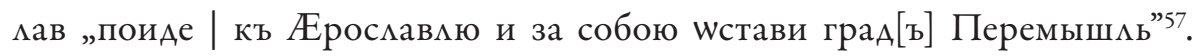
Жители Ярослава пытались предотвратить осаду города, однако - безуспешно ${ }^{58}$. Обустроив позиции, руководство венгерско-польской армии организовало под стенами осажденного Ярослава рыцарский турнир, в котором принял участие и сам Ростислав Михайлович: „сразившюсл| емоу съ Воршем[ь], и падесл пшА[ъ] ним[ь] конь, и вырази собъ | плече"59. МежАу тем князь Ааниим отправим к городу Аворского Андрея, чтобы передать известие о приближающейся армии обоих Романовичей ${ }^{60}$. Битва под Ярославом завершилась полным разгромом венгерско-польских сим ${ }^{61}$, после чего „Ааним[ъ] же гороА[ъ] заж[ь]же, | еже Ростис-

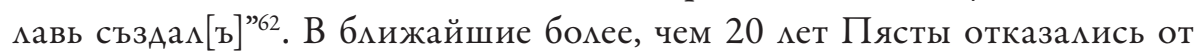

55 Ibidem, s. 274.

56 Ibidem, s. 272.

57 Ibidem, s. 272-273.

58 „Столщю ж[е] емоу [Ростислава Михайловича. - M.B.] оу града и стро^щю порокы, имиже $\mid$ прїимет[ь] граА[ъ], и быс[ть] бой велїй преА[ъ] граАшм[ь] [акцент наш. - М.В.].

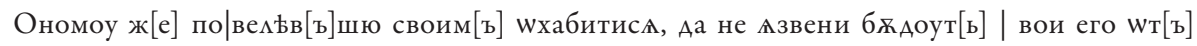
гражанъ, Аон[в]_еже оустроит[ь] сжаы пороч[ь]ные”, Ibidem, s. 273.

59 Ibidem, s. 274.

60 „Посла|ста ж[е] АндрђА, Аа их[ъ] виАит[ь] и оукрђпит[ь] граА[ъ], æко оуже близ[ъ] ес[ть $] \mid$ сп[а]ссее]нїе их[ъ]”, Ibidem, s. 275.

${ }^{61}$ Vide: из последнего о битве: М. Котияр, Нариси воєнного мистеитва Аавнвої Русі, реА. Н. САюСАРенко, Київ 2010, s. 94-97; А. ГАРАІ, Руські та угорські джерела про князя Ростислава Михайловича в Ярославській битві, або до питання про історію лицарськой кульmури, Записки НТШ, Аьвів 2012, вип. 264: праці Історично-філософської секції, s. 368 373; В. ПЕтегирич, Битва під Ярославом 1245 року: археологічний коментар до літописної розповidi, [w:] Colloquia Russica, red. V. Nagirny, T. Pud£ocki, series II, vol. 1: Przemyśl iziemia Przemyska w strefie wptywów ruskich X - potowa XIV w., Kraków 2013, s. 101-111; M. Bonoщук, Просопографічні студї̈ битви під Ярославом 17 серпня 1245 року, [w:] Colloquia Russica, series II, vol. 3, реА. В. НАГІрний, М. ВолОщук, Івано-Франківськ-Краків 2017, s. 117-119; Ђ. ХАрАи, Итинерариј Ростислава Михаиловича Сремска Митровииа, Нови СаА 2019, s. 78-85, а также прим. 275 - самый полный из последних очерк историографии битвы.

${ }^{62}$ Chronica Galiciano-Voliniana, s. 285. 
каких-либо вторжений в сосеАние земли, но со смертью короля Ааниима в 1264 г. межАинастические конфмикты возобнови ись.

Так в 1266 г. князь Болеслав Стыдмивый обвинив Шварна Аанииловича († ок. 1269) в подстрекании нападений митовцев на его земли, „почаша мАхове воевати окомо | Хомма [акцент наш. - М.В.] [...] И не взАша ниче-

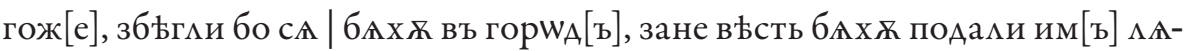
хове-оу|краинАне"63. В том же году в ответ на контрмеры князя Шварна и Володимира Васимьковича († 1288) „цАхове почаша воевати | около Чръвна [акцент наш. - М.B.] [...] и не взем[ъ]ше ничегож[е], и тако пои|Аоша назаА $[ъ] " 64$, а по результатам победы в том же году 19 июня наА Романовичами в урочище Ворота „АА хове [...] поидоша къ Бемзоу [акцент наш. - M.B.], и поча воевати и села жечи”. ОАнако после контратаки Васимька


В целом военные действия польских сил в окрестностях Хомма, Червена и Белза нанес и существенный ущерб главным образом сельской местности, однако сами города не пострадами.

Обусловленную разными обстоятельствами более чем 10-летнюю паузу в 1279 г. с одной стороны прерваци подстрекания князем Болесцавом Володимира Васицьковича к военным Аействиям против своего племянника, сына Земовита († 1262) - черского князя Конрада $(† 1294)^{66}$,

${ }^{63}$ Ibidem, s. 456-457.

${ }^{64}$ Ibidem, s. 458.

${ }^{65}$ Ibidem, s. 459-460. Поражение князя Шварна поА Воротами отображено анналами (Rocznik kapituty krakowski, [w:] MPH, t. 2, ed. A. BIELOwsKI, Lwów 1872, s. 808; Rocznik franciszkański krakowski 1202-1288, [w:] MPH, t. 3, ed. A. MA£eCKI, W. KęTRZyńsKi, X. Liske, Lwów 1878, s. 48, vide: Rocznik krótki krakowski, [w:] MPH, t. 2, ed. A. BIELOwski, Lwów 1872, s. 808; Rocznik krakowski, [w:] MPH, t. 2, ed. A. Bielowski, Lwów 1872, s. 839; Rocznik Traski, [w:] MPH, t. 2, ed. A. Bielowski, Lwów 1872, s. 839; Rocznik Sędziwoja, [w:] MPH, t. 2, ed. A. Bielowski, Lwów 1872, s. 878; Rocznik Świętokrzyski do r. 1490, [w:] MPH, t. 3, ed. A. MAŁECKI, W. KęTRZyŃSKI, X. Liske, Lwów 1878, s. 75; Rocznik Matopolski, A. Bielowski, [w:] MPH, t. 3, ed. A. MAŁECKI, W. Kętrzý́ski, X. Liske, Lwów 1878, s. 171; Rocznik kujawski 1202-1376, [w:] MPH, t. 3, ed. A. MaŁecki, W. KętrZyŃski, X. Liske, Lwów 1878, s. 206; Zdarzenia godne pamięci 966-1516, [w:] MPH, t. 3, ed. A. MA£eCKi, W. KęTrZy Ński, X. Liske, Lwów 1878, s. 308), известно авторам Каталогов краковских епископов (Catalogi episcoporum Cracoviensium, s. 113), так называемой Вемикопольской хроники (Chronica Poloniae Maioris, s. 121) и Я. Алугошу (Dlugossir JoANNES, Annales seu Cronicae incliti regni Poloniae, lib. 7-8, Warszawa 1975, s. 150, 155).

66 „ВъАшАимер[ъ] же посла на Кондрата рат[в] свою, и воеваша|по сей сторонъ Вислы, и взАша полона много", Chronica Galiciano-Voliniana, s. 497. 
а с Аругой - смерть 7 декабря 1279 г. самого Болеслава СтыАливого, вы-

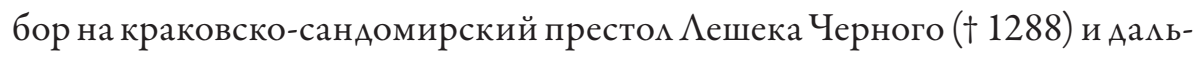
нейшее на рубеже 70-80-х гг. XIII в. соперничество с ним, при активном содействии татар, Аьва Ааниимовича († ок. 1300) ${ }^{67}$. В ответ на поход по-


оу него горша[ъ] Переворескь [акцент наш. - М.B.], и исъсьче весь шт[ъ] мала до вели|ка, и горшА заж[ь]же, и поиде назаА[ъ] въ своа си"68. К Аанным событиям приналяежат и следующие сообщения хроники Романо-

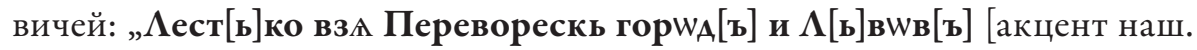
- M.B.], | то ж[е] $\Lambda$ хове воеваша оу Берестїа [акцент наш. - М.В.] по Кръснь, и взАша сем[ъ] | Аеслт[ь], и поидоша назаА[ъ]"69.

По результатам более жесткого подчинения наследников короля $\mathrm{Aa}$ ниима монгольским Чингизидам, общего с ними похода руських войск в Венгрию и Аацьнейшего обострения отношений с Пястами (при участии Романовичей во внутреАинастической борьбе послеАних) первой половины 80-х гг. XIII в., на протяжении 1285-1286 гг. мазовецкий князь


Ibidem, s. 500. Vide: S. Krakowski, Obrona pogranicza wschodniego Matopolskiza Leszka Czarnego, „Zeszyty Naukowe Uniwersytetu Łódzkiego. Nauki humanistyczne” 1960, R. 1, nr 15, s. 97-114.

${ }^{68}$ Chronica Galiciano-Voliniana, s. 504.

69 Ibidem, s. 524. Часть плена с Берестья горожанам удамось успешно отбить: „Берестїане ж[е] събрашас $[\AA]$ и гнаша|поних[ъ], бАше бо А^ховь са берестїань о $[. .$.$] побъдиша берестїане$

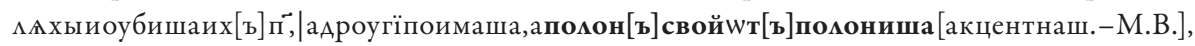
и тако | прїидоша въ Берестїи съ ч[ь]стїю” (Ibidem, s. 524-525). Опустошитемьный характер кампании Аешека Черного, хотя и без детального описания взятия городов, подтвержАают анналы („dux Lestco [...] spolians Russiam et castra subvertens [акцент наш. - M.B.], reversuque est ad propria cum gloria et pace”, Rocznik franciszkański krakowski 1202-1288, s. 51; vide: Rocznik Traski, s. 847; Rocznik Sędziwoja, s. 878; Rocznik Matopolski, s. 181; Catalogi episcoporum Cracoviensium, s. 100). Описывает его и Я. Аһугош („Lestko Niger repellere bellum, nisi inferret, parum ratus, post dies quindecim exercitibus adunatis et recensitis, cum triginta milibus equitum et duobus peditum magis expeditorum Leonem insecutus terras suas Russie invadit multaque castra [акцент наш. - M.B.] a Ruthenis deserta aut minus iusto presidio locata occupant, expugnat et evertit et usque ad Leopolim [акцент наш. - М.B.] terra populata, predam frequentam tam hominum, quam pecorum Leone in ulteriora Russie diffugiente et decernere non audente, Poloniam adduxit", Dlugossi Joannes, op. cit., lib. 7-8, s. 211). Vide: к теме: P. ŻMudZki, Studium podzielonego Królestwa: ksiażę Leszek Czarny, Warszawa 2000, s. 288-289, а также: Ł. JAROs, Dziatalność militarna księcia krakowskiego, sandomierskiego i sieradzkiego Leszka Czarnego w latach 1279-1288, „Rocznik Oddziału Polskiego Towarzystwa Historycznego w Skarżysku-Kamiennej. Z dziejów Regionu i Miasta" 2014, t. 5, s. 20-21. 
Болеслав († 1313) „воева около Щекарева [акцент наш. - М.В.] | и взА Аеслт[ь] семъ"70. Сам город однако не пострадам. По результатам кампании монголов в Польшу в 1287 г., эпидемии („Тое ж[е] sимы [1287/8 г. - M.В.] и в $\Lambda$ ххох[ъ] быс[ть $]$ моръ великь, изомре $\mid$ их[ъ] бесчислен[ь]ное множ[ь]ство” ${ }^{71}$, последующих самостоятемьных ими же при содействии с татарами частых и нередко очень успешных походов русинов в приграничные с королевством Руси земли (Аюблинская, Краковско-Сандомирская, Мазовецкая) ${ }^{72}$ ими же достаточно отдаленные (Симезия) ${ }^{73}$ Пясты пристановими военные действия в ответ вплоть до начала XIV в., когда

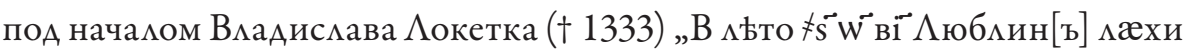
wт[ъ]шүками шт[ъ] руси”. Аатировка события в источниках отмичается. Кроме 1302 г. можно встретить также 1306 г. $^{74}$

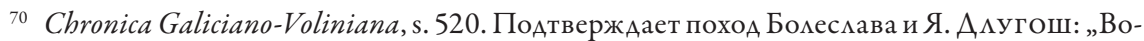
leslaus Maszovie dux [...] terram Russie ingressus [...] magna spolia Maszoviam refert”, Dlugossil JoAnnes, op. cit., lib. 7-8, s. 237. По результатам кампании в ответ отряды Романовичей „начаша воевати около Вышегорода [акцент наш. - М.В.], и поимаша бе|счислен[ь]ное мншж[в]ство и скота, и конеи" (Chronica Galiciano-Voliniana, s. 522).

${ }^{71}$ Chronica Galiciano-Voliniana, s. 537, 539; vide: „Eodem anno fuit maxima fama in terra Cracoviensi”, Rocznik Traski, s. 848; Rocznik Sędziwoja, s. 879). Vide: Т. ХайАаров, «Моръ и глад» на территории Руси и в Золотой Орде ( $X$ - первой половины XIV вв.), „Тюркологические исследования" 2018, т. 1, № 2, s. 87; А. Порсин, Заговор Ногая против Тула-Буги в контексте эпидемиологической ситуации в Золотой Орде последней четверти ХІІІ века, [w:] Эпидемии и природнье катаклизмы в Золотой Орде и на сопредельньцх территориях (XIII-XVI вв.). Сборник научных статей, реА. И. МирГАлеЕв, Казань 2018, s. 72.

72 Chronica Galiciano-Voliniana, s. 579, 636, 648. Vide: Rocznik Traski, s. 853. Vide:Z. SzAmBELAN, Najazdy ruskie na ziemię Sandomierską $w$ XIII wieku, „Acta Universitatis Lodziensis. Folia Historica”, 1989, nr 36, s. 7-32; J. TĘGOWsKI, Ruś Halicka $i$ Wtodzimierska w kontaktach rodzinnych i politycznych Wtadystawa Eokietka, [w:] Король Аанило Романович: культурна

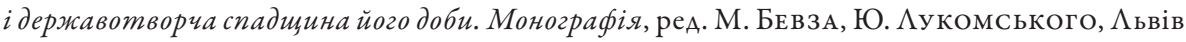
2016, s. 262-267.

${ }^{73}$ Chronica Galiciano-Voliniana, s. 637, 639, vide: 647, а также: Rocznik cystersów henrykowskich, [w:] MPH, t. 3, ed. A. MaŁeCKi, W. Kętrzyński, X. Liske, Lwów 1878, s. 702. Vide: к теме: N. Miкa, Polityka czeska kniazia Lwa Danitowicza. $Z$ dziejów stosunków rusko-czeskich $w$ drugiej potowie XIII wieku, [w:] Colloquia Russica, series II, t. 1, red. V. Nagirny, T. PudŁocki, Kraków 2013, s. 168-169, 173-174, 176.

${ }^{74}$ Chronica Galiciano-Voliniana, s. 649. Vide: „Eodem anno inierunt milites Cracovienses et Sandomirienses Russiam, videlicet Lublin novum, quod Rutheni occupaverunt pluribus annis [акцент наш. - M.B.], expugnaverunt deinde de paucis cum multitudine Ruthenorum, et Lithwanorom et Tartharorum pugnaverunt, et Domino cooperante de omnibus triuphaverunt", Rocznik Traski, s. 853; Vide: Rocznik Sędziwoja, s. 879; Rocznik Świętokrzyski do r. 1490, s. 77; Rocznik 
Последние же сопровожАавшиеся взятим (ими сАачей) городов военные кампании Пястов в земли королевства Руси, связаны с Казимиром III († 1370). Аатируемые апрелем - маем $1340^{75}$ и terminus ante quem 1 Аекабря 1349 гг. ${ }^{76}$ походы послеАнего завершались не только взятием

Matopolski, s. 188; Zdarzenia godne pamięci 966-1516, s. 309, а также: Dlugossir Joannes, Annales seu Cronicae incliti regni Poloniae, Warszawa 1975, lib. 9, s. 20. К теме опанования Аюблина


sunkach między Polską iksięstwem halicko-wtodzimierskim w XIII wieku, [w:] Nibil superfluum esse. Studium zdziejów średniowiecza ofiarowane Profesor Jadwidze Krzyżanowskiej, red. J. STRZELCZY K, J. Dobosz, Poznań 2000, s. 229-236.

75 „Audiens Kazimirus, rex Polonie, quod ita vita decessisset, Russiam circa festum pasche in parvo numero intrans, christianos et mercatores, qui se in castro Liwow receperant, castro cremato [акцент наш. - М.B.] cum uxoribus, pueris et rebus eurum usque in regnum suum deduxit”, Rocznik Traski, s. 860. Vide: Maлопольские aннaль: „Audiens rex Polonie eximius Kazimirus, quod ita vita decessisset Russiam circa festum pasche in parvo numero intrans christianos et mercatores, qui se in castro Lywow vel Lamberg receperant, castro cremato [акцент наш. - M.B.] cum uxoribus eorum et pueris et rebus eorum usque in regnum suum deduxit”, Rocznik Matopolski, s. 200. Vide: „Kazimirus Rex Polonie [...] cum exercitu suo terram Russie dictam gentem expugnaturus intravit", Vetera Monumenta Poloniae et Lithuaniae gentiumque finitimarum historiam illustrantia, deprompta collecta ac serie chronologia disposita ab A. Theiner, Romae 1860 , t. 1, s. 434; „rex Krakovie racione consortis, que filia regis Livonie fuerat, terram apprehendere festinavit, et abductis inde spoliis pluribus, quibusdam civitatibus depredatis [акцент наш. - M.B.] ad propria est reverses", Iohannis abbatis Victoriensis liber certanum historiarum, ed. F. SchneIder, t. 2, lib. IV-VI, [w:] Monumenta Germaniae historica. Scriptores rerum Germanicarum in usum scholarum, Hannoverae-Lipsiae 1910, s. 218; „Kazimirus rex Poloniae praelibatus cum magna potentia gentis suae regnum Russiae potenter ingressus", Joannis de Czarnkow, Chronicon Polonorum, [w:] MPH, t. 2, ed. A. Bielowski, Lwów 1872, s. 621. Vide: „in Poloniam incolumis et victor atque spoliis largicionibusque et donis Ruthenorum magnificatus, remeabat", Dlugossii Joannes, op. cit., lib. 9, s. 216; „В сие и пойде на Русь”, Густьиская летопись, [w:] ПСРА, т. 40, реА. В. БугАнов, Б. РЫбАков, Санкт-Петербург 2003, s. 129. Очерк источников vide: H. PAszkiewicz, Polityka ruska Kazimierza Wielkiego, Warszawa 1925, s. 66-70, 81-83.

76 „прииде король Краковьскыи со многою силою взяша Аестью землю Волыньскую”, Новгородская первая метопись старшего и мкаАшего изводов, [w:] ПСР $\Lambda$, т. 3, Москва 2000, s. 361; „король краковскій взя местію землю Волынскую и много зАа хрестьяномъ створи”, Типографская лютопись, [w:] ПСРА, т. 24, Петроградъ 1921, s. 119; „В то ж Волынь хотяще отлучитися от короля Казимера, но мечемъ укрочены быша”, Густынская метопись, s. 129; vide: также свидетельства Аругих, так или иначе идентичных по содержанию, Аетописей: Аетопись по Воскресенскому списку, s. 215; Аптописный сборникъ, именуемьий льтописью Авраамки, [w:] ПСРА, т. 16, Санкт-Петербургъ 1889, s. 82; Аьвовская льтопись, [w:] ПСРА, т. 20, ч. 1, Санкт-Петербургъ 1910, s. 185; Eрмолинскалльтопись, [w:] ПСРА, т. 23, Санкт-Петербургъ 1910, s. 109; Московский летописный свод конща XV века, 
столицы - Аьвова и некоторых Аругих городов, но и грабительским вывозом в Польшу королевских инсигний Романовичей, выведением горожан ${ }^{77}$. ОАнако с большой натяжкой их можно считать походами против конкретно представителей „по мечу” Аинастии Рюриковичей, хотя непосредственно на их наследие претендовац король Польши. Учитывая, что отравленный в волынском Володимире 21 марта 1340 г. Юрий-Болес-


и даже будущий коромь Помьши ВАаАислав II Ягайло († 1434) яв я иись наследниками отдельных земель королевства Руси иск ючите ьно „по куАели”, мы не рассматриваем кампаний при их непосредственном участии ими организации. ГАавными соперниками Казимира III и его союзников за переде и идержание недавно завоеванных неодноратно упоминаемых источниками земель и городов Алительное время главным образом оставались именно Аитовские князья.

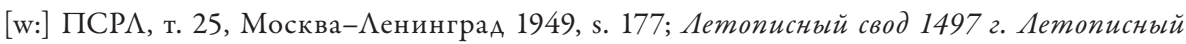
свод 1518 г. (Уваровская летопись), [w:] ПСРА, т. 28, Москва-АенинграА 1963, s. 72, 233; Холмогорская летопись. Авинской летописеи, [w:] ПСРА, т. 33, АенинграА 1977, s. 83; Постниковский, Пискаревский, Московский и Бельский летописиь, [р:] ПСРА, т. 34, Москва 1978, s. 111 и Ар., а также маконичные известия к теме матиноязычной группы источников: „Rex Kazimirus terram Russie obtinuit”, Rocznik Miechowski, [w:] MPH, t. 2, ed. A. Bielowski, Lwów 1872, s. 885; „Anno 1349 Casimirus rex Polonie cum magna potencia intravit Russiam eam sibi subiugando", Annalista Thorunensis, [w:] Scriptores rerum Prussicarum, Bd. 3, herausgegeben von Th. Hirsch, M. Töppen, E. Strehlke, Leipzig 1866, s. 78. Vide: Joannis de Czarnkow, op. cit., s. 629, Dlugossin Joannes, op. cit., lib. 9, s. 255. Оставим в Аанном случае без более детального анализа версию возможного военного захвата в 1344/5 г. Казимиром III Сяноцкой земли с ее городами. Vide: H. PASzkiewicz, Polityka ruska Kazimierza Wielkiego, s. 91-105; D. WróBel, Polityka wschodnia Kazimierza Wielkiego w kontekście środkowoeuropejskim, „Rocznik Niepołomicki” 2010, t. 2, s. 141.

77 Значительный выведенный Казимиром III весной 1340 г. плен post factum при описании татарского нападения на Польшу в 1341 г. подтвержАает и „Хроника” Францишека Пражского: „rex eorum cum alio rege condixerat ad invadendum christianos, qui precedendi anno extiterat devictus", Kronika Františka Pražského, [w:] Fontes rerum Bohemicarum, t. 4, ed. J. EMLER, Praha 1884, s. 430 . 


\section{BIBLIOGRAFIA*}

\section{Źródła drukowane}

Густьнскал летопись, [w:] Полное собрание русских летописей, т. 40, отв. реА. В. Буганов и Б. Рыбаков, Санкт-Петербург 2003.

Ермолинская лютопись, [w:] Полное собрание русских летописей, т. 23, СанктПетербургъ 1910.

Ипатьевская летопись, [w:] Полное собрание русских летописей, с предисловием Б. М. Кносса, т. 2, иза. 2, Москва 2001.

Аетописныцй свод 1497 г. Аетописныцй свод 1518 г. (Уваровская летопись), [w:] Полное собрание русских летописей, т. 28, Москва-ИенинграА 1963.

Аетопись по Воскресенскому списку, [w:] Полное собрание русских летописей, с предисловием Б. Клосса, т. 7, Москва 2001.

Аьвовскал лптопись, [w:] Полное собрание русских летописей, т. 20, ч. 1, СанктПетербургъ 1910.

Аютописный сборникб, именуемьий лютописью Авраамки, [w:] Полное собрание русскихлетописей, т. 16, Санкт-Петербургъ 1889.

Московский летописньй свод кониа XV века, [w:] Полное собрание русских летописей, т. 25, Москва- АенинграА 1949.

Новгородскал первая летопись старшего и младшего изводов, [w:] Полное собрание русских летописей, т. 3, Москва 2000.

Постниковский, Пискаревский, Московский и Бельский летописиь,, [w:] Полное собрание русских летописей, т. 34, Москва 1978.

Типографская лютопись, [w:] Полное собрание русских летописей, т. 24, ПетрограАъ 1921.

Холмогорскаялетопись. Авинскойлетописещ, [w:] Полное собраниерусскихлетописей, т. 33, АенинграА 1977.

Annalista Thorunensis, [w:] Scriptores rerum Prussicarum, herausgegeben von Th. Hirsch, M. Töppen, E. Strehlke, Bd. 3, Leipzig 1866, s. 57-464.

Catalogi episcoporum Cracoviensium, recensuit et annotavit J. Szymański, Nova series, [w:] Monumenta Poloniae historica, t. 10, f. 2, Warszawa 1974.

Chronica Galiciano-Voliniana (Chronica Romanoviciana), eds D. Dąbrowski, A. Jusupović, [w:] Monumenta Poloniae historica, Nova series, t. 16, Kraków-Warszawa 2017.

* Bibliografia zawiera źródła i opracowania wykorzystane w obu częściach artykułu Гopoda Pycu в военных операчиях Пястов против Рюриковичей (XI - середина XIV вв.). Część druga znajduje się w „Oblicza Wojny”, t. 5: Miasto i wojna, red. W. Jarno, J. Kita, Łódź 2021, s. 49-66. 
Chronica Poloniae Maioris, recen. et annot. B. Kürbis, [w:] Monumenta Poloniae historica, Nova series, t. 8, Warszawa 1970.

Cronica Petri comitis Poloniae accedunt carminis Mauri fragmenta, edidit, praefatione notisque instruxit M. Plezia, [w:] Monumenta Poloniae historica, seria 2, t. 3, Kraków 1951.

Die Chronik des Bischofs Thietmar von Merseburg, herausgegeben von R. Holtzmann, [w:] Monumenta Germaniae historica. Scriptores Rerum Germanicarum, Nova series, t. 9, München 1996.

Dlugossii Joannes, Annales seu Cronicae incliti regni Poloniae, komit. red. Z. Kozłowska-Budkowa i in., lib. 1-2, Warszawa 1964.

Dlugossii Joannes, Annales seu Cronicae incliti regni Poloniae, komit. red. Z. Kozłowska-Budkowa i in., lib. 3-4, Warszawa 1970.

Dlugossii Joannes, Annales seu Cronicae incliti regni Poloniae, komit. red. Z. Kozłowska-Budkowa i in., lib. 5-6, Warszawa 1973.

Dlugossii Joannes, Annales seu Cronicae incliti regni Poloniae, komit. red. Z. Kozłowska-Budkowa i in., lib. 7-8, Warszawa 1975.

Dlugossii Joannes, Annales seu Cronicae incliti regni Poloniae, komit. red. Z. Kozłowska-Budkowa i in. lib. 9, Warszawa 1975.

Gallus Anonymus, Gesta Principum Polonorum, translated annotated by P. W. Knoll and F. Schaer with a preface by Th. N. Bisson, [w: Central European Medieval Texts, vol. 3, general editors J. M. Bak, U. Borkowska, G. Constable, G. Klaniczay, Budapest-New York 2003.

Homza M., Uhorsko-pol'ská kronika. Nedocenený prameň k dejinám strednej Európy, Bratislava 2009.

Iohannis abbatis Victoriensis liber certanum historiarum, t. 2, lib. IV-VI, ed. F. Schneider, [w:] Monumenta Germaniae historia. Scriptores rerum Germanicarum in usum scholarum, Hannoverae-Lipsiae 1910.

Joannis de Czarnkow, Chronicon Polonorum, [w:] Monumenta Poloniae historica, t. 2, ed. A. Bielowski, Lwów 1872, s. 619-756.

Kronika Františka Pražského, [w:] Fontes rerum Bohemicarum, t. 4, ed. J. Emler, v Praze 1884, s. 347-456.

Magistri Vincentii dicti Kadłubek, Chronica Polonorum, ed. M. Plezia, [w:] Monumenta Poloniae historica, seria II, t. 11, Kraków 1994.

Rocznik cystersów henrykowskich, [w:] Monumenta Poloniae historica, t. 3, ed. A. Małecki, W. Kętrzyński, X. Liske, Lwów 1878, s. 699-704.

Rocznik franciszkański krakowski 1202-1288, [w:] Monumenta Poloniae historica, t. 3, ed. A. Małecki, W. Kętrzyński, X. Liske, Lwów 1878, s. 46-52.

Rocznik kapituty krakowski, [w:] Monumenta Poloniae historica, t. 2, ed. A. Bielowski, Lwów 1872, s. 779-782. 
Rocznik krakowski, [w:] Monumenta Poloniae historica, t. 2, ed. A. Bielowski, Lwów 1872, s. 827-860.

Rocznik krótki krakowski, [w:] Monumenta Poloniae historica, t. 2, ed. A. Bielowski, Lwów 1872, s. 792-808.

Rocznik kujawski 1202-1376, [w:] Monumenta Poloniae historica, t. 3, ed. A. Małecki, W. Kętrzyński, X. Liske, Lwów 1878, s. 204-212.

Rocznik Matopolski, A. Bielowski, [w:] Monumenta Poloniae historica, t. 3, ed. A. Małecki, W. Kętrzyński, X. Liske, Lwów 1878, s. 135-202.

Rocznik Miechowski, [w:] Monumenta Poloniae historica, t. 2, ed. A. Bielowski, Lwów 1872, s. 880-896.

Rocznik Sędziwoja, [w:] Monumenta Poloniae historica, t. 2, ed. A. Bielowski, Lwów 1872, s. 871-879.

Rocznik Świętokrzyski do r. 1490, [w:] Monumenta Poloniae historica, t. 3, ed. A. Małecki, W. Kętrzyński, X. Liske, Lwów 1878, s. 53-86.

Rocznik Traski, [w:] Monumenta Poloniae historica, ed. A. Bielowski, Lwów 1872, t. 2, s. 826-860.

Vetera Monumenta Poloniae et Lithuaniae gentiumque finitimarum historiam illustrantia, deprompta collecta ac serie chronologia disposita ab A. Theiner, t. 1, Romae 1860.

Zdarzenia godne pamięci 966-1516, [w:] Monumenta Poloniae historica, t. 3, ed. A. Małecki, W. Kętrzyński, X. Liske, Lwów 1878, s. 296-313.

\section{Opracowania}

Волощук М., Просопографічні студї битви під Ярославом 17 серпня 1245 року, [w:] Colloquia Russica, ред. В. Нагірний, М. Волощук, series II, vol. 3, Івано-ФранківськКраків 2017, s. 103-122.

Волощук М., Руські бранці Арпадів та угорські бранці Рюриковичів XI-XIII ст.: порівня ььний аспект, „Byzantinoslovaca” 2020, № VII, s. 121-133.

ГарАі А., Руськітаугорськіджерелапрокнязя Ростислава Михайловича в Ярославській битві, або до питання про історію лищарської культури, „Записки НТШ”, вип. 264: праці Історично-філософської секції, $\Lambda$ ьвів 2012, s. 368-373.

Гіппіус О., Міхеєв С., Нові методики досліджень та прочитання графіті церкви Святого Пантелеймона ХII-XIII cm, [w:] Галич. Збірник наукових праць, реА. М. Волощук, вип. 5, Івано-Франківськ 2020, s. 17-44.

Головко А., Аревняя Русь и Польша в политических взаимоотношениях $X$ - первой трети ХІІІ вв, Киев 1988.

Головко О., Західнобузькі міста Холм і Аорогочин у політичній діяльності короя Аанила Романовича, [w:] Арогичинг 1253, реА. О. Жернокмеєв, М. Волощук, I. Гурак, Івано-Франківськ 2008, s. 50-63. 
Головко О., Князв Роман Мстиславович та його доба, Київ 2001.

Головко О., Русь і Польща у політичних взаємовідносинах середини XII cm, [w:] Проблеми історії країн Центральної та Східної Європи: збірник наукових праць, редкол. В.С. Степанков (головн. реА.) та ін., вип. 3, Кам'янець-Подільський 2012, s. 47-55.

ГоловкоО., Участь польського жнязя Болеслава Першого «Хороброго» уміжкнязівській війні на Русі (літо - осінь 1018 р.), „Наукові прачі Кам'янещь-Подільського начіонального університету ім. Івана Огієнка. Історичні науки” 2018, № 28, s. $55-71$.

Корнієнко В., Eпіграфіка сакральних пам’яток Галича (XII-XIX cm.), [w:] Галич. Збірник наукових праць, реА. М. Волощук, серія 2, вип. 3, Івано-Франківськ 2018.

Котмяр М., Нариси воєнного мистецтва Аавньої Русі, гол. реА. Н. САюсаренко, Київ 2010.

Пашкевич Г., Початки Галича, [w:] Галич. Збірник наукових праць, ред. М. Волощук, вип. 5, Івано-Франківськ 2020, s. 96-108.

Петегирич В., Битва під Ярославом 1245 року: археологічний коментар долітописной розповidi, [w:] Colloquia Russica, red. V. Nagirny, T. Pudłocki, series II, vol. 1: Przemyśl i ziemia przemyska w strefie wptywów ruskich X - potowa XIV w., Kraków 2013, s. $101-111$.

Порсин А., Заговор Ногая против Тула-Буги в контексте эпидемиологической ситуачии в Золотой Орде последней четверти ХІІІ века, [w:] Эпидемии и природные катаклизмы в Золотой Орде и на сопредельных территориях (XIII-XVI вв.). Сборник научных статей, науч. реА. И. Миргалеев, Казань 2018, s. $63-74$.

Хайдаров Т., «Морь и глад» на территории Руси и в Золотой Орде (X - первой половины XIV вв.), „Тюркологические исследования” 2018, № 1 (2), s. 73-100.

Харди Ђ., Итинерариј Ростислава Михаиловича, Сремска Митровица, Нови СаА 2019.

Щавелева Н.,Аревняя Русь в «Польской истории» Яна Алугоша (книги I-VI): текст, перевод, комментарии, Москва 2004.

Юрасов М., Венгрия и русские княжества в XII веке: Аиссертация..., Аоктора исторических наук. 07.00.02 - отечественная история, Москва 2017.

Юрасов М., Роль Перемьция в борьбе Владимира Ярославича за возврашение Галича (1189-1190), [w:] Colloquia Russica, red. V. Nagirny, T. Pudłocki, series II, t. 1, Kraków 2013, s. 67-77.

Benyskiewicz K., Czy Bolestaw Chrobry dwukrotnie wyprawiat sie przeciwko Jarostawowi Mąremu? Interpretacja 65 rozdziatu siódmej księgi Kroniki Thietmara, „Наукові праці Кам’янець-Подільського націонацьного університету ім. Івана Огієнка. Історичні науки" 2018, № 28, s. 219-234. 
Benyskiewicz K., Zniszczenie Wiślicy w 1135 roku w świetle przekazów źródtowych i literatury historycznej, część I: Źródta), „In Gremium” 2020, t. 14, s. 39-67.

Debate I. Ruthenians in Poland and Poles in Rus' in the $11^{\text {th }}-13^{\text {th }}$ centuries, [w: Colloquia Russica, red. V. Nagirny, Kraków 2019, series I, vol. 9: Rus' and Poland (10 $10^{\text {th }}-14^{\text {th }}$ centuries). Publications from the $9^{\text {th }}$ International Scientific Conference, Przemysil, $5^{\text {th }}-8^{\text {th }}$ December, 2018, s. 359-371.

Delestowicz N., Bolesław II Szczodry. Tragiczne losy wielkiego wojownika 1040/1042 - 2/3 IV lub 1081 albo 1082, Kraków 2016.

Gawron J., Najazdy książat halicko-włodzimierskich na ziemię lubelska w latach 1243$1244 w$ świetle średniowiecznych źdódet narracyjnych, „Koło Historii” 2015, nr 17, s. 53-61.

Hudáček P., Castrum Salis. Severné pograničie Uhorska okolo roku 1000, Bratislava 2016.

Jaros Ł., Dziatalność militarna księcia krakowskiego, sandomierskiego i sieradzkiego Leszka Czarnego w latach 1279-1288, „Rocznik Oddziału Polskiego Towarzystwa Historycznego w Skarżysku-Kamiennej. Z dziejów Regionu i Miasta” 2014, t. 5, s. 5-32.

Jusupović A., «Червенв и иньце градыљ» or «Гродь Червеньскьял»? History of the domain of Cherven' in the written record (10 ${ }^{\text {th }}-13^{\text {th }}$ Centuries), [w:] From Cherven' Towns to Curzon Line Od Grodów Czerwieńskich do linii Curzona, vol. III: U źródet Europy Środkowo-Wschodniej/Frühzeit Ostmitteleuropas, ed. M. Wołoszyn, Kraków-LeipzigRzeszów-Warszawa 2017, s. 31-105.

Jusupović A., Przynależność polityczna Drohiczyna w XII i pierwszej potowie XIII w., [w:] Арогичинг 1253, реА. О. Жернокмеєв, М. Волощук, І. Гурак, Івано-Франківськ 2008, s. 159-170.

Jusupović A., Żaden książ nie wszedt tak daleko w ziemię lacka jak Wtodzimierz Wielki. Wydarzenia z końca X wieku i ich recepcja w XIII wieku, [w:] Materiaty V Kongresu mediewistów polskich, t. 3: Pogranicza w polskich badaniach mediewistycznych, red. A. Janeczek, M. Parczewski, M. Dzik, Rzeszów 2019, s. 55-77.

Kollinger K., Polityka wschodnia Bolestawa Chrobrego (992-1025), Wrocław 2014.

Krakowski S., Obrona pogranicza wschodniego Matopolski za Leszka Czarnego, „Zeszyty Naukowe Uniwersytetu Łódzkiego. Nauki humanistyczne” 1960, R. 1, nr 15, s. 97-114.

Mika N., Polityka czeska kniazia Lwa Danitowicza. Z dziejów stosunków rusko-czeskich $w$ drugiej potowie XIII wieku, [w:] Colloquia Russica, series II, t. 1, red. V. Nagirny, T. Pudłocki, Kraków 2013, s. 163-181.

Myśliński K., Problemy terytorialne w stosunkach między Polska i księstwem halicko-wtodzimierskim w XIII wieku, [w:] Nibil superfluum esse. Studium z dziejów średniowiecza ofiarowane Profesor Jadwidze Krzyżanowskiej, red. J. Strzelczyk, J. Dobosz, Poznań 2000, s. 229-236.

Nagirnyj W., Polityka zagraniczna księstw ziem halickiej i wołyńskiej w latach 1198 (1199)_ 1264, Kraków 2011. 
Paszkiewicz H., Początki Rusi, z rękopisu przygotował K. Stopka, Kraków 1996.

Paszkiewicz H., Polityka ruska Kazimierza Wielkiego, Warszawa 1925.

Szambelan Z., Najazdy ruskie na ziemię Sandomierską w XIII wieku, „Acta Universitatis Lodziensis. Folia Historica” 1989, nr 36, s. 7-32.

Tęgowski J., Rus Halicka $i$ Wtodzimierska $w$ kontaktach rodzinnych i politycznych Wtadystawa Eokietka, [w:] Король Аанило Романович: культурна і державотворча спадщина його доби. Монографія, піс реА. М. Бевза, Ю. Аукомського, Аьвів 2016, s. 262-267.

Urbańczyk P., Bolestaw Chrobry - lew ryczacy, Toruń 2017.

Voloshchuk M., Ruthenian-Polish matrimonial relations in the context of the inter-dynastic policy of the house of Rurik in the $11^{\text {th }}-14^{\text {th }}$ centuries: selective statistical data, "Codrul Cosminului" 2019, vol. XXV, no. 1, s. 95-126.

Włodarski B., Polityka Ruska Leszka Biatego, „Archiwum Towarzystwa Naukowego we Lwowie" 1925, dział II, t. 3, z. 3.

Włodarski B., Polska i Ruś 1194-1340, Warszawa 1966.

Włodarski B., Ruś w planach politycznych Bolestawa Krzywoustego (1102-1138), „Zeszyty Naukowe Uniwersytetu Mikołaja Kopernika w Toruniu. Nauki humanistyczno-społeczne" 1966, historia II, z 20, s. 37-57.

Wróbel D., Polityka wschodnia Kazimierza Wielkiego w kontekście środkowoeuropejskim, „Rocznik Niepołomicki” 2010, nr 2, s. 101-167.

Zientara B., Bolestaw Wysoki - tutacz, repatriant, malkontent, Kraków 2013.

Żaki A., Przemyśl w czasach Bolestawa Chrobrego i Mieszka II, „Rocznik Przemyski. Archeologia” 2005, t. 41, z. 2, s. 145-156.

Żmudzki P., Studium podzielonego Królestwa: książe Leszek Czarny, Warszawa 2000.

\title{
Myroslav Voloshchuk
}

\section{CITIES OF RUS' IN THE MILITARY OPERATIONS OF THE PIASTS AGAINST THE RURIKIDS (11 - MID- OF THE 14 CENTURIES). PART $1^{78}$}

\begin{abstract}
The article is devoted to the analysis of the military campaigns of the Piasts into the lands of the Rurikids with further siege, assault and the capture of the Ruthenian towns or entry into them without any resistance. In general considering very active interdynasty dialogue in all possible planes, at the same time we emphasize the high intensity of the invasions of the Poles into the neighboring eastern lands. The total number of the campaigns that ended during the 11th - 14th centuries with the devastation of the towns of the Rurikids
\end{abstract}

78 The second part of the article can be found in: Oblicza wojny, t. 5: Miasto i wojna, eds W. Jarno, J. Kita, Łódź 2021, s. 49-66. 
or their environs was at least 24. In addition, the Poles more than 10 times entered in Rus', appearing in certain cities as a defenders, an allies, a guardians, a protectors of the local Ruthenian princes, especially during the first decades of the 13th century. Among the most dramatic in the aftermath of the looting were the entry of Boleslav the Brave into Kyiv in 1018 , the capture of Volhynian Volodymyr by Leszek the White in $1207 / 8$, and also by Leszek the Black in 1280 - Lviv and Perevoresk. The example of the capture of Lviv by Casimir III in 1340 - should be consider separately. At the same time, with the exception of the description of the siege in August 1245 by Yaroslav, we do not have any other evidence of the engineering thought, tactics and strategy of the preparing for an assaults and the capture of Rus'ian fortifications by the Piast. It is quite possible that the sources simply did not attach much importance to this.

Keywords: the Piasts, the Rurikids, Ruthenian towns, war, siege, assault, statistics 